\title{
Influence of waste solutions of detergent-sanitizers upon environment at sanitization of reservoirs of dairy truck cisterns
}

\author{
O. Zhukorskiy, \\ Doctor of Agricultural Sciences \\ National Academy of Agrarian Sciences of Ukraine \\ Ye. Kryvohyzha, \\ Candidate of Veterinary Sciences \\ Institute of Agroecology and Nature Management NAAS
}

The purpose. To study efficiency of sanitization of reservoirs of dairy truck cisterns and to analyze receipt of working matters of applied detergent-sanitizers in natural circumambient (NC). Methods. Sanitary-and-hygienic, microbiological, mathematical and statistical. Results. Results of study of efficiency of sanitization of reservoirs of dairy truck cisterns are brought at application of detergent-sanitizers Dezmol and Hyproclor ED. The level of receipt of chemicals of detergentsanitizers after sanitization of reservoirs of dairy truck cisterns in milk processing factories into city sewage buildings with subsequent interception in NC is analyzed and theoretically possible breaking in natural biotic communities are justified. Conclusions. Application of Hyproclor ED for sanitization of reservoirs of dairy truck cisterns is more efficient in compar-I son with Dezmol. Chlorine substances will arrive into environment at use of Dezmol and Hyproclor ED for the purpose of sanitization of reservoirs of dairy truck cisterns. However at application of Hyproclor ED there is no receipt into EC of waste solutions of detergent-sanitizers with the contents of phosphate, sulphonol and silicates that reduces probability of breaking natural biotic communities.

Key words: detergent-sanitizers, sanitization, reservoirs of dairy truck cisterns, natural circumambient.

Problem. The dairy industry is strategically important for the economy of Ukraine. It occupies an important place in the structure of the food industry and is the leading element in addressing food security [1]. At different stages of social development problems of efficiency of milk production and its quality were still relevant [2]. In addition, the system of milk production is a major source of pollution of natural and artificial ecosystems through emissions of greenhouse gases and other pollutants. [3] Most dairy farms can be classified as dangerous for the natural environment production facilities [4].

The main indicator of milk quality that characterizes its technological properties as the raw material is bacterial contamination. Delivery of cow's milk with the high microbiological indicators quality to the reprocessing enterprise is possible only if proper sanitary processing of the whole complex of dairy and milking equipment on farms [5]. Cooling milk for 2 hours. to $+4{ }^{\circ} \mathrm{C}$ and storing it on a dairy farm not more than 24 hours [6]. Also on sort of milk at an acceptance on a reprocessing enterprises the efficiency influence of cleaning and disinfection milk tank truck [7] and conditions transportation milk [8].

For washing and disinfection of objects of veterinary supervision at a production and transportation of cow's milk used by a large number of detergents and detergent disinfectants, containing phosphates. However phosphates when hit in sewage and water bodies cause a flowering blue-green algae, leading to a sharp reduction in dissolved oxygen, and this, in turn, contributes to eutrophication (flowering) water and results in death fish and "dying off lake" [9]. In addition, a large number of detergents and detergents disinfectants containing anionic surfactants that are able to persist long in the natural environment and pollute natural water bodies, including household purposes $[10,11]$.

In the European Union introduced many changes to limit the harmful effects of household chemicals, including banned realize the market products that contain surfactants, biodegradability is below $80 \%$ [12]. However, the problem of safety of these substances has not been fully resolved. Therefore, the analysis of the environmental problems in the application of detergents and disinfectants for cleaning and disinfection of milk tank truck is important and necessary. 
Analysis of recent researches and publications. The problems of obtaining and transport to dairy plants of milk of quality on microbiological indexes studied YA.Y. Kryzhanivskyj [5], M.D. Kuhtyn [6], L.G. Vasilyev [8]. Environmental confusions in the application of detergents and disinfectants investigated M.J. Scott [10], T. Ivanković [11] V.I. Belova [13]. Since the issue of efficiency detergent disinfectant for sanitary processing of mobile milk tanker and the level of income solutions in the natural environment is not fully understood, this issue needs to be further addressed.

The purpose of research. To study the efficiency of sanitary processing of milk tank truck and analyze the level of income of active substances used detergents disinfectants means in the natural environment.

Material and methods of research. Research efficiency of sanitary processing of milk tank truck conducted on dairy enterprises Ternopil region. Sanitary processing of milk tank truck carried out after draining milk from them using the washing unit. Herewith two washing heads with nozzles the installed in place of the hatch cover. With automatic sprayers, under pressure of sprinkle water for rinse and solutions of the investigated means. The process of sanitary processing the inner surface of the milk tank in the sequence occurred following operations: previous rinse of internal surface of the milk tank by water of temperatures $+35-45{ }^{\circ} \mathrm{C}$ during $3-5$ minutes; treatment solution detergents disinfectants of the investigated means by temperature $+50-60{ }^{\circ} \mathrm{C}$; rinse of milk tank of residues detergent disinfectant by water of temperatures $+35-45^{\circ} \mathrm{C}$ for $3-5$ minutes.

The comparative estimation of efficiency of sanitary processing of milk tank were conducted using present at the market of Ukraine alkaline detergents disinfectants means: Dezmol (active substances - soda ash, sulphonol, sodium tripolyphosphate and inhibitor of corrosion) and Hyproclor ED (sodium hydroxide and sodium hypochlorite). All means employ in concentrations and the temperature according to the instructions for use. Control of the sanitary state of milk tank was conducted in according to the generally accepted methodologies.

Analysis of level of receipt of chemical active substances of detergents disinfectants means after realization of sanitary processing of milk tank truck on dairy enterprises in urban sewage edifice with a further hit in the natural environment were conducted the calculations.

The main material. The efficiency of sanitary processing of milk tank truck using working solutions of detergent disinfectants means, including Dezmol and Hyproclor ED presented in table 1.

1. Microbiological research bacterial sampling from the inner surfaces of milk tank truck when using detergent disinfectants means, $M \pm m, n=15$

\begin{tabular}{|c|c|c|c|}
\hline \multirow{2}{*}{$\begin{array}{l}\text { Name of means, } \\
\text { concentration } \\
\text { solution }\end{array}$} & \multirow{2}{*}{$\begin{array}{l}\text { Time of taking of bacterial } \\
\text { sampling }\end{array}$} & \multicolumn{2}{|c|}{$\begin{array}{l}\text { Bacterial content of sampling from the objects } \\
\text { research, thousand } \mathrm{CFU} / \mathrm{ml}\end{array}$} \\
\hline & & milk tanks & prefabricated milk \\
\hline \multirow[t]{3}{*}{$\begin{array}{l}\text { Dezmol, } \\
0,3 \%\end{array}$} & $\begin{array}{l}\text { before processing (milking milk } \\
\text { for control) }\end{array}$ & $429,4 \pm 10,4$ & $368,9 \pm 10,4$ \\
\hline & after processing & $86,9 \pm 2,4^{*}$ & $135,4 \pm 2,1^{*}$ \\
\hline & effectiveness, \% & 79,8 & 63,3 \\
\hline \multirow[t]{3}{*}{$\begin{array}{l}\text { Hyproclor ED, } \\
0,5 \%\end{array}$} & $\begin{array}{l}\text { before processing (milking milk } \\
\text { for control) }\end{array}$ & $427,8 \pm 11,2$ & $389,4 \pm 11,7$ \\
\hline & after processing & $2,1 \pm 0,3^{*}$ & $87,2 \pm 1,9^{*}$ \\
\hline & effectiveness, \% & 99,5 & 77,6 \\
\hline
\end{tabular}

Note. ${ }^{*}-\mathrm{P} \leq 0,001-$ in relation to the processing.

From the data table 1 shows that the sanitary processing of milk tank truck using $0,5 \%$ solution means Hyproclor ED reduced the microbial contamination of the inner surface of milk tank truck in 204,1 times $(P \leq 0,001)$, compared with the initial level of microbial contamination $(427,8-429,4$ thousand CFU $/ \mathrm{ml})$. The number of microorganisms constitute $2,1 \pm 0,3$ thousand $\mathrm{CFU} / \mathrm{ml}$. After sanitary processing of milk tank truck by a $0,5 \%$ solution of Dezmol working solutions by temperature $+60 \pm 5{ }^{\circ} \mathrm{C}$ of bacterial sampling the microbial number decreased in 4,9 times $(P \leq 0,001)$ and was on average $86,9 \pm 2,4$ thousand $C F U / m l$. 
In studying the microbiological quality prefabricated milk that is transported in the in milk tanks trucks, the sanitary processing of which was conducted at application of mean of Dezmol set that milk from the coolers of farms with maintenance of microorganisms 30-40 thousands CFU/ml was carriage on a dairy enterprises with microbial count 130-140 thousand $\mathrm{CFU} / \mathrm{ml}$, which corresponds the highest sort. At application of mean of Hyproclor ED this milk from the coolers of farms was delivered on a dairy enterprises with a bacterial content 80 90 thousand $\mathrm{CFU} / \mathrm{ml}$, that answers to the extra of sort.

Taking into account content of operating substance of the used solutions of detergents disinfectants means and amount of treatments for defined periods of time (for one treatment, day and year) we calculated flow of the used means after of sanitary processing of milk tanks trucks in city sewer system. The obtained data are driven to the table 2.

2. Proceeds active substances detergents disinfectants means after of sanitary processing of milk tanks trucks on dairy enterprises in city sewer system

\begin{tabular}{|c|c|c|c|c|c|}
\hline \multirow{2}{*}{$\begin{array}{l}\text { Name } \\
\text { means }\end{array}$} & \multirow{2}{*}{$\begin{array}{c}\text { Active } \\
\text { substances }\end{array}$} & \multirow{2}{*}{ 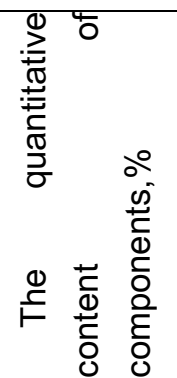 } & \multicolumn{3}{|c|}{$\begin{array}{l}\text { Proceeds solutions detergents disinfectants means } \\
\text { after their use in natural environment on } 10 \text { milk tanks } \\
\text { trucks, kg }\end{array}$} \\
\hline & & & $\begin{array}{cc}\text { for } & \text { one } \\
\text { treatment }\end{array}$ & day & year \\
\hline \multirow{4}{*}{ Dezmol } & хлорамін Б & 20,0 & 1,0 & $8,0-10,0$ & $2920,0-3650,0$ \\
\hline & $\begin{array}{l}\text { триполіфоосфат } \\
\text { натрію }\end{array}$ & 20,0 & 1,0 & $8,0-10,0$ & $2920,0-3650,0$ \\
\hline & сульфонол & 2,0 & 0,1 & $0,8-1,0$ & $292,0-365,0$ \\
\hline & $\begin{array}{l}\text { метасилікат } \\
\text { натрію }\end{array}$ & 30,0 & 1,5 & $12,0-15,0$ & $4380-5475$ \\
\hline $\begin{array}{l}\text { Hyproclor } \\
\text { ED }\end{array}$ & $\begin{array}{l}\text { гіпохлорит } \\
\text { натрію }\end{array}$ & 10 & 0,5 & $4,0-5,0$ & $1460-1825$ \\
\hline
\end{tabular}

As seen in table 2 shows that hit of chemicals in city sewer system by the use of a means of Dezmol during year will be, an average of phosphate 3285,0 kg/year, sulphonol 328,5 kg/year and silicates $4927,5 \mathrm{~kg} / \mathrm{year}$, that in turn, predetermines violation of natural biocenosiss.

By use of Hyproclor ED and Dezmol for sanitary processing 10 milk tanks trucks during year hit of chlorinated substances into the natural environment will $1642,5 \mathrm{~kg}$ and $3285,0 \mathrm{~kg}$ respectively. During the educe a chlorine in the natural environment formed resistant organic halogen compounds (dioxins) having carcinogenic, mutagenic and teratogenic properties $[13,14]$. Dioxins are extremely insoluble in water. Getting in the rivers, they settle in a silt and soil and accumulate in fabrics of hydrobionts, where their concentration in the hundreds of thousands of times higher than in water. The feature of dioxins is their ability to bioaccumulation. Dioxins are chemically stable compounds. Therefore time of their half-decay in the natural environment is very long: from 29 to 139 years for various dioxin-like compounds [15]. Transference of dioxin in food chains leads to their concentration in organisms, fish, mammals and humans, that presents a danger.

\section{Conclusions}

Efficiency of the use mean of Dezmol for sanitary processing of milk tanks trucks is $79.8 \%$, that not sufficiently for their proper care, resulting in increased bacterial contamination of milk. Sanitary processing of a $0,5 \%$ solution of means of Hyproclor ED allows to bring down the microbial contamination of internal surfaces of milk tank truck, on the average, on $99,5 \%$, that diminishes the level of hit the primary of microflora in milk by transporting.

Determined that the use of drugs Hyproclor ED and Dezmol for sanitary processing 10 milk tanks trucks in during to the year in the natural environment will reach chlorinated substances $1642,5 \mathrm{~kg}$ and $3285,0 \mathrm{~kg}$ respectively. 
Application mean of Hyproclor ED is safer, as there is no flow in the hydrosphere residues of detergents disinfectants means, including phosphates 2920,0-3650,0 kg year, sulphonol 292,0-365,0 kg/year and silicates 4380-5475 $\mathrm{kg} /$ year.

The use of multicomponent active substances for the detergents disinfectants means does not always provide high efficiency of sanitary processing of milk tanks trucks and increases the amount of flow of chemicals in the natural environment.

Prospects of subsequent researches. Further signification of influence of the used detergents disinfectants means in the production of goods of stock raising, that penetrate in the natural environment on the state of biocenosiss is essential for the sustainable functioning of ecosystems.

\section{Bibliography}

1. Koval'ov, A.I., Karpov, V.A., Vynokurova, O.I. (2015). Zastosuvannya «transportnoyi zadachi» dlya optymizatsiyi lohistychnykh vytrat u molochniy promyslovosti [Using of "transport task" for optimization of logistic costs for the dairy industry]. Ekonomichni innovatsiyi [Innovative economy], 59:29-35 [in Ukrainian].

2. Binert, O.V. (2013). Yakist' molochnoyi produktsiyi yak konkurentna perevaha na rynku [Quality dairy products as a competitive advantage in the market]. Ekonomichni innovatsiyi [Innovative economy], 1 (39):205-207 [in Ukrainian].

3. Zhukors'kyy, O.M., Nykyforuk, O.V., Boltyk, N.P. (2015). Emisiya parnykovykh haziv vid koriv na fermakh iz vyrobnytstva moloka [The emissions of greenhouse gases from cows on farms producing milk]. Visnyk ahrarnoyi nauky [Bulletin of Agricultural Science], 5:45-48 [in Ukrainian].

4. Zhukors'kyy, O.M., Boltyk, N.P. (2015). Model' otsinyuvannya stanu ahroekolohichnoyi systemy vedennya molochnoho skotarstva [The model Assessment state of agroecological system conduct of dairy cattle]. Aktual'ni problemy suchasnoyi biolohiyi, tvarynnytstva ta veterynarnoyi medytsyny : materialy mizhnarodnoyi naukovopraktychnoyi konferentsiyi, 2-3 zhovtnya 2015 r. [Actual problems of modern biology, animal husbandry and veterinary medicine : Materials of the international scientific-practical conference, October 2-3, 2015]. Biolohiya tvaryn [The Animal Biology], 17, 3:167 [in Ukrainian].

5. Kryzhanivs'kyy, Ya.Y., Kryvokhyzha, Ye.M. (2009) Naukove zabezpechennya sanitarnoyi obrobky doyil'nykh ustanovok ta molochnoho posudu na fermi. Retrospektyva, suchasnyy stan [Scientific support of sanitary processing milking equipment and dairy tableware on the farm. Retrospective, modern state]. Naukovyy visnyk LNUVMBT imeni S.Z. Gzhyts'koho [Scientific Messenger LNUVMBT named after S.Z. Gzhytskyj], 11, 4, 2(41):115120 [in Ukrainian].

6. Kukhtyn, M.D. (2011). Teoretychne obgruntuvannya veterynarno-sanitarnykh normatyviv i rozroblennya systemy kontrolyu vyrobnytstva moloka korov"yachoho nezbyranoho okholodzhenoho [Theoretical substantiation of veterinary and sanitary norms and production system control development of whole cows milk] : avtoref. dys. na zdobuttya nauk. stupenya doktora vet. nauk [The summary of the dissertation for the scientific degree of Doctor of veterinary medicine sciences] : spets. 16.00.06 "Hihiyena tvaryn ta veterynarna sanitariya". L'viv, 39 [in Ukrainian].

7. Dronyk, H.V. Kryvokhyzha, Ye.M., Saranchuk, I.I., Klepach, D.V. (2015). Sanitarna obrobka tsystern molokovoziv ekolohichno bezpechnym myyno-dezinfikuyuchym zasobom Sandez [Sanitary processing of milk tanks trucks of environmentally safe detergent disinfectant mean of Sandez]. Ekolohichnyy stan i zdorov"ya zhyteliv mis'kykh ekosystem. Horbunovs'ki chytannya : tezy dopovidey, 5 travnya 2015 r. [Ecological state and health of inhabitants of urban ecosystems. Horbunov's readings : thesis report, May 5, 2015]. Chernivtsi: «Misto», 66-67 [in Ukrainian].

8. Vasil'ev, L.G., Abramova-Obolenskaya, N.I., Pavlov, V.A. (1990). Gigienicheskoe i protivoepidemicheskoe obespechenie proizvodstva moloka i molochnykh produktov [Hygiene and anti-epidemic providing of production of milk and dairy products]. Moscow : Agropromizdat, 303 [in Russian].

9. Postanova VRU (2010) «Pro rozroblennya Zahal'noderzhavnoyi prohramy shchodo zmenshennya ta postupovoho prypynennya vykorystannya na terytoriyi Ukrayiny myynykh zasobiv na osnovi fosfativ». [Decision of the Verkhovna Rada of Ukraine «On the development of the National Program to reduce and gradually stop using the territory of Ukraine detergents based on phosphate»] Dokument 2335-17. Pryynyato vid 15.06.2010 // 
Vidomosti Verkhovnoyi Rady Ukrayiny [The Official Bulletin of the Verkhovna Rada of Ukraine], $38: 512$ [in Ukrainian].

10. Scott, M.J., Jones, M.N. (2000). The biodegradation of surfactants in the environment. Biochimica et Biophysica Acta, 1508:235-251.

11. Ivanković, T. Hrenović, J. (2010). Surfactants in the environment. Arh Hig Rada Toksikol, 61:95-110.

12. Regulation (EC) No 648/2004 of the European Parliament and of the Council of 31 March 2004 on detergents [in Europe].

13. Belova, V.I., Volkov, Yu. P. (1991) Osnovnye napravleniya issledovaniy v razrabotke dezinfitsiruyushchikh sredstv [The main areas of research in the development of disinfectants]. Sb. n. tr. NII vaktsin i syvorotok. Nauchnye osnovy dezinfektsii i sterilizatsii [Collection of Scientific Papers Research Institute of Vaccines and Sera. Scientific basis disinfection and sterilization], Moscow, 13-18 [in Russian].

14. Alcock, R. E., Jones, K. C. (1996) Dioxins in the Environment: A Review of Trend Data. Environ. Sci. Technol, 30 (11):3133-3143.

15. Bryukhovets'ka, I.V., Kropyvnyts'ka, L.M. (2011). Dioksyny: osnovni dzherela vynyknennya ta shlyakhy nadkhodzhennya $v$ navkolyshnye seredovyshche [Dioxins: basic sources of onset and ways of get into the natural environment]. Khimichna osvita $v$ konteksti khimichnoyi bezpeky: stan problemy i perspektyvy: zbirnyk tez dopovidey Mizhnarodnoyi naukovo-praktychnoyi konferentsiyi, 25-26 lyutoho $2011 \mathrm{r}$. [Chemical education in the context of chemical safety: state and prospects of research: Coll. of thesises and abstracts International scientific and practical conf., 25-26 February, 2011]. Kyiv, 41-43 [in Ukrainian]. 